\title{
ALK NM 004304.4:C.3521T>G
}

National Cancer Institute

\section{Source}

National Cancer Institute. ALK NM 004304.4:C.3521T>G. NCI Thesaurus. Code C146868.

A nucleotide substitution at position 3521 of the coding sequence of the ALK gene where thymine has been mutated to guanine. 